\title{
Anti-mitotic and anti-proliferation potentials of aqueous and methanolic extracts of fermented Citrullus vulgaris (ogiri-egusi) seeds
}

\author{
*1,3Ayo-Lawal, R. A., ${ }^{2}$ Azeez, S. O. and ${ }^{3}$ Osoniyi, 0. \\ ${ }^{1}$ National Centre for Technology Management (NACETEM), Obafemi Awolowo University, Ile-Ife, Nigeria \\ ${ }^{2}$ Department of Botany, Obafemi Awolowo University, Ile - Ife, Nigeria \\ ${ }^{3}$ Department of Biochemistry and Molecular Biology, Obafemi Awolowo University, Ile - Ife, Nigeria
}

\begin{abstract}
There is a growing scientific evidence of the health-enhancing benefits of fermented food and beverages, especially in cancer prevention and treatment. Ogiri-egusi is an indigenously fermented condiment consumed in some West African countries, and prepared mainly from natural fermentation of melon (Citrullus vulgaris) seeds. The condiment has been previously reported to possess anti-oxidative and anti hyperlipid emic properties. In this study, different concentrations of ogiri-egusi extracts were exposed to actively dividing cells from Allium cepa meristematic roots and Saccharomyces cerevisiae for the antimitotic and antiproliferative investigations, respectively. There was a statistically significant reduction in mitotic activities of the treated $A$. cepa meristematic cells compared to the untreated cells. The mitotic index (MI) of the untreated cells was $28.38 \pm 4.58$. At a concentration of $1.0 \mathrm{mg} / \mathrm{ml}$, the extracts induced a reduction in the MI to $6.02 \pm 2.74$ and $4.94 \pm 0.61$ in the aqueous and methanolic extracts- treated cells, respectively. Some chromosomal aberrations were also observed. In addition, proliferation in yeast cells was significantly inhibited at all the concentrations of the aqueous extract examined as well as at the highest concentration of the methanolic extract. These results provide useful insights to the cytotoxic and genotoxic effects of fermented Citrullus vulgaris.
\end{abstract}

Keywords: Fermented Citrullus vulgaris, Allium cepa, antiproliferation, cytotoxicity, genotoxicity

*Corresponding author: e-mail; ayoronkelawal@gmail.com;

\section{Introduction}

Cancer is the second leading cause of death globally, and was responsible for an estimated 9.6 million deaths in 2018 (WHO, 2018). Among other characteristics, incessant proliferation is an important part of cancer development and progression. The cancer cells therefore develop systems to survive beyond their normal life span and proliferate abnormally in a process involving mitosis (Feitelson et al., 2015). Mitosis is an important and elaborate process in actively proliferating cells, resulting in the division of duplicated sets of chromosomes and producing two genetically identical daughter cells (Chan et 
al., 2012). The vulnerability of cancer cells when they undergo division serves as a critical intervention point in chemotherapy. The strategy involves a prolonged arrest of cells in mitosis, culminating in mitotic cell death (Chan et al., 2012). Among plant species, Allium cepa assay has been used to evaluate disturbances in the mitotic cycle and chromosome aberrations (Khanna and Sharma, 2013). The test has been used for monitoring the genotoxic, cytotoxic and mutagenic nature of different test chemicals.

Fermented foods and beverages have been an integral part of the human diet since time immemorial, with unproven potential health-enhancing properties.

The traditional beliefs regarding the medicinal importance of some fermented foods are now scientifically verified. Medicinal

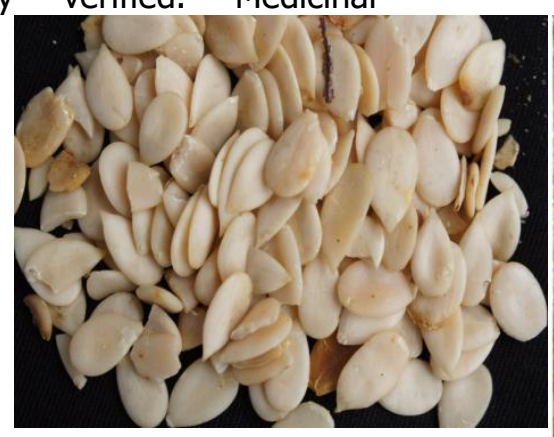

importance varies from one fermented product to another and includes quicker digestion of protein and carbohydrates, removal of natural toxins in food, improved mental health and lipid profile, antidiabetic, etc (Marshall and Mejia, 2011; Kwak et al., 2012; Park et al., 2014; Selhub et al., 2014). In addition, some fermented foods have been reportedly beneficial in cancer prevention and treatment (Park, 1995; Hur et al., 2000; Kris-Etherton et al., 2002; Mueller and Voigt, 2011).

Ogiri egusi (Figure 1) is a condiment prepared naturally by fermentation of melon (Citrullus vulgaris) seeds. It is consumed in many West African countries (Odunfa, 1981; Achi, 2005), and is locally known as ogiri-egusi in many parts of Nigeria.

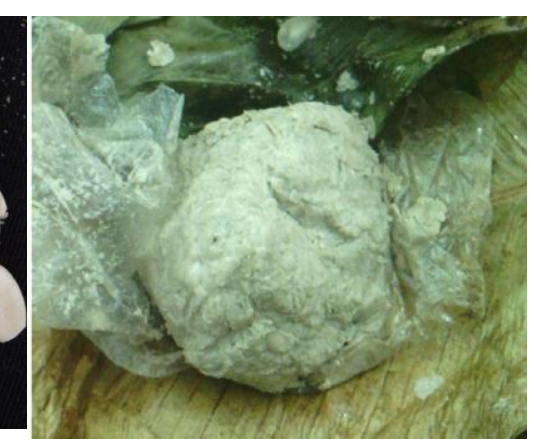

Figure 1: Citrullus vulgaris (melon) seeds (A) were used to prepare Ogiri-egusi (B) uncontrolled solid state fermentation.

It is an important condiment useful as a nutritious, functional, non-meat protein supplement in soups and sauces (Mortarjemi, 2002; Achi, 2005). Furthermore, ogiri-egusi is rich in antioxidants (Ayo-Lawal et al., 2015) and has a number of medicinal properties; for instance, the oil extracted from the condiment after fermentation has been reportedly useful for medicinal purposes by traditional healers (Ajayi and Ajayi, 2009). Supplementation of feed with ogiri-egusi also significantly increases the plasma levels of HDL-C and reduces the LDL-C cholesterol in tyloxapol induced hyperlipidaemic rats (Ayo-Lawal et al., 2015). This study aimed to investigate the potential effects of ogiri-egusi extracts on actively proliferating cells. The possible genotoxic, anti-mitotic and antiproliferation activities were examined using the $A$. cepa and yeast cell proliferation models.

\section{Materials and Methods}

Aqueous and methanolic extraction from fermented Citrullus vulgaris seeds

Indigenously prepared fermented $C$. vulgaris seeds (FCVs) were purchased from a local industry and were manually smoothened using a mortar and pestle in the laboratory to form a smooth, uniform paste. The aqueous extract of FCVs was obtained by soaking the paste in distilled water $(1: 5 \mathrm{w} / \mathrm{v})$ for $48 \mathrm{~h}$ with constant stirring. The supernatant was collected and the residue squeezed in a mesh cloth to 
obtain all the extract. The extract was freeze- dried (CHRiST BETA 1-8 LD Plus, Germany) to obtain a dried marc. To obtain the methanolic extract, a known weight of the original paste was extracted with methanol $(1: 5 \mathrm{w} / \mathrm{v})$ in the Soxhlet apparatus for $18 \mathrm{~h}$. The methanol solution was subsequently concentrated in a rotary evaporator (Buchi RII, Switzerland) set at $40^{\circ} \mathrm{C}$.

Anti-mitotic evaluation of the extracts of fermented $C$. vulgaris seeds

Allium cepa assay was used to investigate the anti-mitotic activity of the extracts as previously described (Gadano et al., 2002; Solange and Haywood, 2012). Dried $A$. cepa bulbs were sprouted in distilled water for $48 \mathrm{~h}$. Sprouted bulbs with uniform roots were grouped and transferred to varying concentrations $(1.0,2.5,5.0,10.0$ and 20.0 $\mathrm{mg} / \mathrm{mL}$ ) of methanolic and aqueous extracts of FCVs for $24 \mathrm{~h}$. Sprouts in distilled water and $0.25 \mathrm{M}$ sodium benzoate were used as untreated and positive control, respectively. After $24 \mathrm{~h}$, the roots were harvested and fixed in 1:3 acetic acid: alcohol. The slides were prepared according to squash technique described by Laosebikan and Olorode (1972). The slides were viewed under a light microscope (Olympus, model CKX31). The photomicrographs were taken with AMSCOPE MT microscope camera version 3.001 attached to a light microscope. Experiments were performed in triplicates.

Mitotic index was expressed as:

Mitotic index $=\left(\frac{\text { number of dividing cells }}{\text { total number of cells }}\right) \times 100 \%$ Mitotic index $=\left(\frac{\text { number of dividing cells }}{\text { total number of cells }}\right) \times 100 \%$

Anti-proliferation evaluation of extracts of fermented $C$. vulgaris seeds

The assay protocol followed was as previously described by Periyanayagam et al. (2013). Briefly, a pure yeast (Saccharomyces cerevisiae) cell inoculum containing $25.4 \times 10^{4}$ cells (average) was prepared in sterilized potato dextrose broth (PDB) referred to as yeast inoculum. The assay mixture consisted of $0.5 \mathrm{~mL}$ yeast inoculum in $2.5 \mathrm{~mL} P D B$, and $1.0 \mathrm{~mL}$ of various concentrations $(1.0,2.5,5.0,10.0$ and $20.0 \mathrm{mg} / \mathrm{mL}$ ) of FCVs aqueous and methanolic extracts (Periyanayagam et al., 2013). Untreated control contained distilled water with no extract, while the positive control contained $1.25 \mathrm{mg} / \mathrm{mL}$ methotrexate. These were incubated at $37^{\circ} \mathrm{C}$ for $24 \mathrm{~h}$. Then, $100 \mu \mathrm{L}$ of mixture was pipetted and thoroughly mixed with equal volume of $0.1 \%$ methylene blue dye. Cell viability was counted using a hemocytometer. Percentage cell viability was calculated as follows:

Viable $=\left(\right.$ average number of viable cell in one square $\times 2 \times$ dilution factor $\left.\times 10^{4}\right)$

Percentage of cell survival $=\left(\frac{\text { total viable cells }}{\text { total number of cells }}\right) \times 100 \%$

\section{Results}

Effects of extracts of fermented $C$. vulgaris on mitotic activity in A. cepa meristematic root cells

The data obtained in this study revealed that the aqueous (Table 1 ) and methanolic (Table 2) extracts of FCVs at the various concentrations negatively affected cell division in treated bulbs unlike the untreated cells. Again, the reduction was directly proportional to the extract concentrations in both cases. The cell division was completely halted at higher concentrations (10 and $20 \mathrm{mg} / \mathrm{ml}$ ) of the two extracts as no dividing cell was observed. Actively dividing cells in all the stages of cell division were observed in cells grown in water (negative control) while sodium benzoate (positive control) showed a total inhibition of mitosis in $A$. cepa meristematic root cells. 
Table 1: Cell count and mitotic indices in $A$. cepa meristematic root cells exposed to various concentrations of aqueous extract of fermented $C$. vulgaris seeds

\begin{tabular}{|c|c|c|c|c|c|}
\hline Treatment & Prophase & Metaphase & Anaphase & Telophase & Mitotic Index (Mean \pm SEM) \\
\hline 0.0 & 1825 & 75 & 100 & 115 & $28.38 \pm 4.58^{*}$ \\
\hline 2.5 & 215 & 40 & 20 & 25 & $5.93 \pm 2.17^{*}$ \\
\hline 5.0 & 75 & 0 & 5 & 5 & $2.67 \pm 1.28^{*}$ \\
\hline 10.0 & 0 & 0 & 0 & 0 & 0 \\
\hline 20.0 & 0 & 0 & 0 & 0 & 0 \\
\hline $\begin{array}{c}\text { Sodium } \\
\text { Benzoate }\end{array}$ & 0 & 0 & 0 & 0 & 0 \\
\hline
\end{tabular}

Notes: $* p<0.05$ statistical difference between FCVs extracts, negative and positive controls $0.25 \mathrm{M}$ Sodium benzoate $=$ positive control

Table 2: Cell count and mitotic indices in $A$. cepa meristematic root tip cells exposed to various concentrations of methanolic extract of fermented $\mathrm{C}$. vulgaris seeds

\begin{tabular}{|c|c|c|c|c|c|}
\hline Treatment & Prophase & Metaphase & Anaphase & Telophase & $\begin{array}{c}\text { Mitotic Index } \\
\text { (Mean } \pm \text { SEM) }\end{array}$ \\
\hline 0.0 & 1825 & 75 & 100 & 115 & $28.38 \pm 4.58^{*}$ \\
\hline 2.5 & 170 & 45 & 5 & 90 & $3.93 \pm 0.65^{*}$ \\
\hline 5.0 & 35 & 25 & 0 & 0 & $1.12 \pm 0.32^{*}$ \\
\hline 10.0 & 0 & 0 & 0 & 0 & 0 \\
\hline $\begin{array}{c}\text { Sodium } \\
\text { Benzoate }\end{array}$ & 0 & 0 & 0 & 0 & 0 \\
\hline
\end{tabular}

Additionally, all normal stages of cell division were observed in untreated and low concentrations-treated cells even though there was reduction in mitotic indices in the latter (Figure 2). Chromosome aberrations were observed in the bulbs treated with $5 \mathrm{mg} / \mathrm{ml}$ aqueous extract. The chromosomes were observed to be more contracted and some cells were more elongated than observed in untreated cells. Laggards were also noted. At 20 $\mathrm{mg} / \mathrm{ml}$, the cells were more elongated and distorted with no dividing cells in aqueous and methanolic extracts, respectively, resulting in the death of the cells (Figure $3)$. 


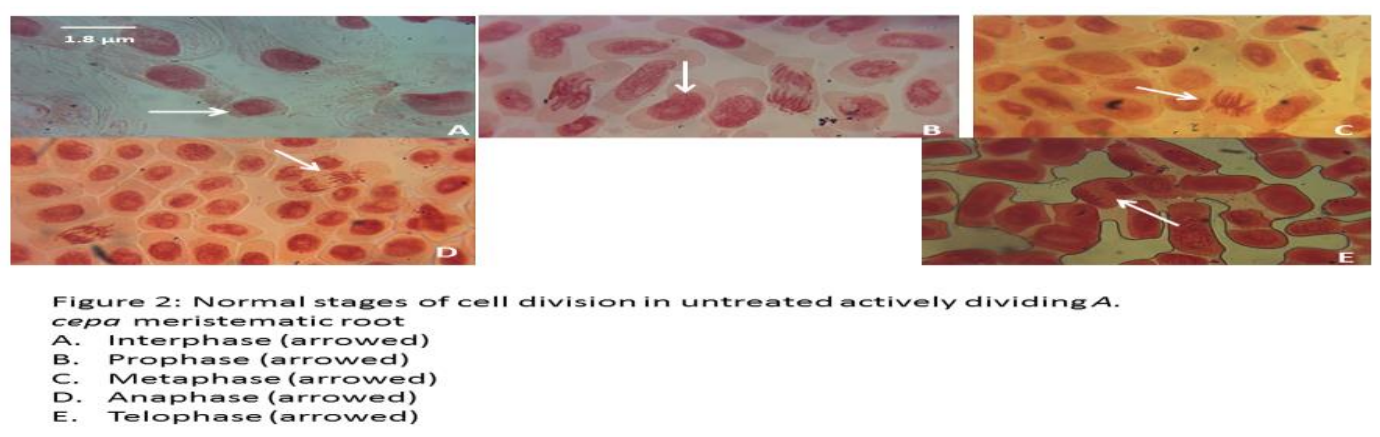

Figure 2: Normal stages of cell division in untreated and low-concentration treated $A$. cepa cells
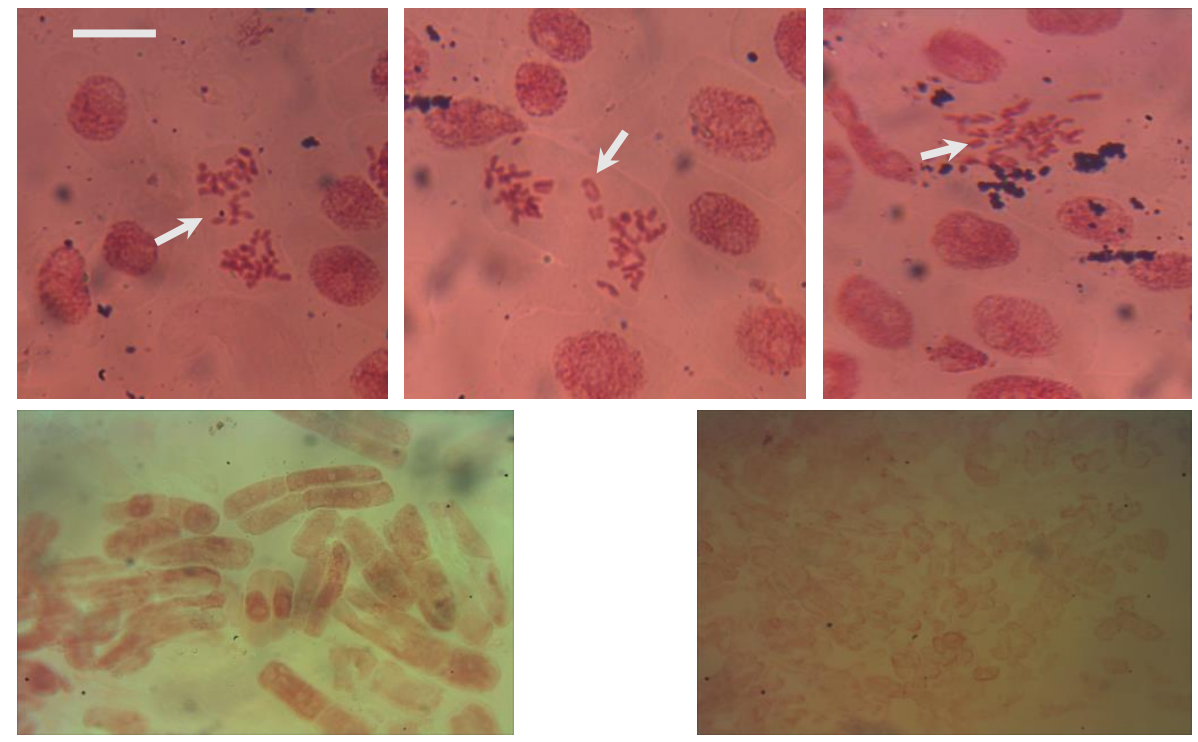

Figure 3: Chromosomal aberrations in $A$. cepa root cells exposed to aqueous and methanolic FCVs extracts

\section{Anti-proliferative activity of FCVs extracts}

There was statistically significant reduction in the rate of proliferation of cultured $\mathrm{S}$. cerevisiae cells exposed to FCVs extracts for $24 \mathrm{~h}$ as concentration of the extract increased compared to the untreated control. Proliferation of yeast cells was significantly inhibited at all the concentrations of aqueous extract (Figure 4) examined. However, activity of the methanolic extract was better described as oscillatory; the significant activity observed at the first two concentrations dropped at the next two and then picked up again at the highest concentration (Figure 5). 


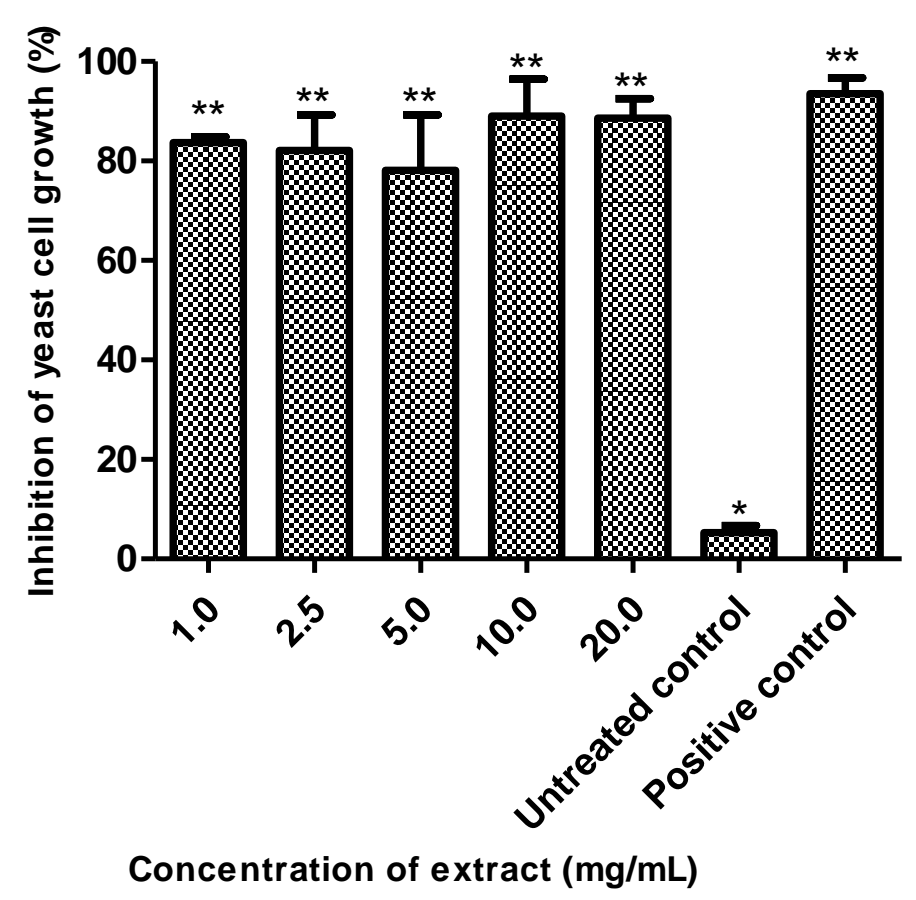

Figure 4: Yeast cells proliferation under the influence of aqueous extract of FCVs. Values represent Mean \pm SEM of three independent readings. $* *$ is significantly different from the untreated control $(*)(p<0.05)$.

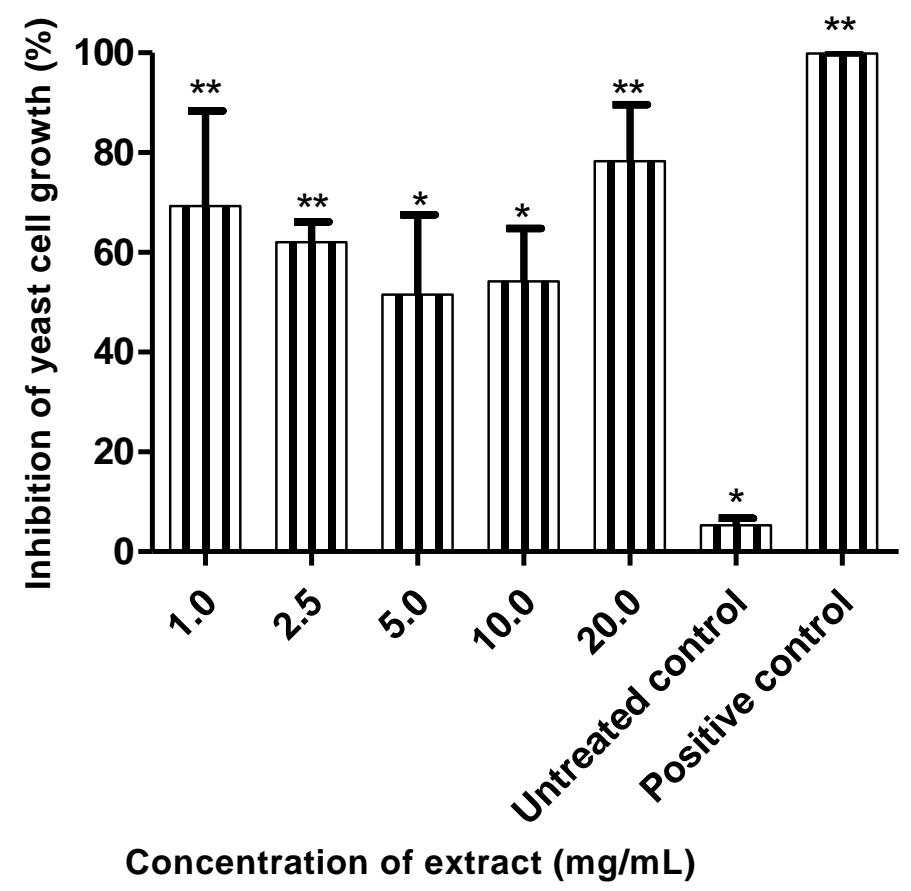

Figure 5: Yeast cells proliferation under the influence of methanolic extract of FCVs. Values represent Mean \pm SEM of three independent readings. $* *$ is significantly different from the untreated control $(*)$, while $*$ is not significantly different from the untreated control $(p<0.05)$.

\section{Discussion}

The $A$. cepa assay is an ideal bio-indicator useful in the identification of the alterations occurring over a cell cycle because the samples are exposed to cells in constant mitotic division (Bagatini et al., 2009). 
Furthermore, the reliability of the test system to evaluate the genotoxic potential of medicinal plants has been established (Knoll et al., 2006; Solange and Haywood, 2012) because the test uses a model that is adequately sensitive to detect numerous substances that cause chromosomal alterations.

This study demonstrates that aqueous and methanolic extracts of fermented $C$. vulgaris seeds inhibited cell division and hence growth in the actively dividing roots of $A$. cepa cells. This was indicated by the reduction in mitotic index, which was long established as an important criterion or indicator of adequate growth and proliferation of tissues (Walker, 1954; Gadano et al., 2002). Furthermore, the aqueous extract was genotoxic to the chromosomes leading to the induction of some aberrations. Higher concentrations of the extract induced aberrations in the chromosomes leading to cell death. The genotoxic potential of various extracts from plants have been previously reported and established using this model (Khanna and Sharma, 2013; Periyanagam et al., 2013; Akinpelu et al., 2019). Induction of aberrations in dividing chromosomes as observed in this study has important biological consequences as it results from wide arrays of DNA changes resulting from cellular exposure to genotoxic agents (Obe et al., 2002). Put together, these results suggest that treatment with the aqueous and methanolic extracts of FCVs impair the integrity of the mitotic materials. A prominent feature of cancer is constant proliferation of cells; anti-mitotic agents are used in cancer management to inhibit abnormal proliferation of transformed cells.

Cell-based assays are important fundamental validation steps and are generally important in the identification of cytotoxic compounds (Barberis et al., 2005). Cancer therapy, involving cytotoxic drugs, kills cells that have a high basal level of proliferation and regeneration (Feitelson et al., 2015). Yeast cells-based assays have been described as excellent model for the cytotoxic screening of natural products due to the genetic malleability and a high degree of relatedness between yeast cellular (cell cycle machinery) processes and those of human cells (Barberis et al., 2005; Qaddouri et al., 2011).

In this study, aqueous extract of FCVs significantly inhibited proliferation in yeast cells at all the concentrations examined compared with control. The methanolic extract showed statistically significant activity compared with control at the lowest (first and second) as well as the highest concentrations. While the highest concentration showed the most potent activity. The results suggested that the extracts of ogiri-egusi possess antiproliferation activity in yeast cells.

\section{Conclusion}

The results of this study revealed that the aqueous and methanolic extracts from ogiri-egusi possessed cytotoxic and genotoxic potentials in the two models adopted in this study. These valuable findings require further investigations for more potent nutraceutics from the condiments. Extract concentrations used in this study are not in any way comparable to the quantity of the condiment used for cooking. Studies are ongoing to investigate the potential activities of these extracts on cancer cell lines and possible apoptotic activity.

\section{Acknowledgement}

The authors thank Prof. O.B. Omafuvbe of the Department of Microbiology, Obafemi Awolowo University, Ile-Ife for kindly providing the yeast isolates and the opportunity to do yeast culture in her laboratory.

\section{References}

Achi, O.K. (2005). The potentials for upgrading traditional fermented foods through biotechnology. AJB. 4(5):315- 380.

Ajayi, O.B., and Ajayi, D.D. (2009). Effect of oilseed diets on plasma lipid profile in albino rats. P.J.N.8:116-118.

Akinpelu, B. A., Godwin, A., Gbadegesin, T., Ajakaye, N., Omotosho, S.E., Azeez, S. O., Oziegbe, M., and Oyedapo, O.O. (2019). Comparative studies on anti- 
inflammatory, antioxidant and antimutagenic activities of Crassocephalum crepidioides (Bent) leaf cold and hot water extracts. Asian Food Science Journal, 9(1): 1-12.

Ayo Lawal, R.A., Osoniyi, R.O., Rivera, G., Elufisan, T.O. (2016). Fermented condiments from melon (Citrullus vulgaris) and African Locust Bean (Parkia biglobosa) seeds - A Review. NIFOJ 34(2):94 - 104.

Ayo-Lawal, R.A., Osoniyi, O. and Famurewa, A.J. (2015). Antihyperlipidaemic and antioxidant potential of fermented Citrullus vulgaris seeds (Thunb.) on tyloxapol-induced hyperlipidaemic rats: a comparison with fluvastatin. JFR, 4(4):110- 119.

Bagatini, M.D., Vasconcelos, T.G., Laughinghouse IV, H.D., Martins, A.F. and Tedesco, S.B. (2009). Biomonitoring hospital effluents by Allium cepa L. test. Bulletin of Environmental Toxicology and Contamination. 82: 590-592.

Barberis, A., Gunde, T., Berset, C., Audetat, S. and Lu"thi, U. (2005). Yeast as a screening tool. Drug Discov. Today Technol. 2(2): 187192.

Chan, K. S., Koh, C. G. and Li, H. Y. (2012). Mitosis-targeted anti-cancer therapies: where they stand. Cell Death and Disease. 411

Feitelson, M.A., Arzumanyan, B., Kulathinal, A., Blain, R.J., Holcombe, S.W., Mahajna, R.F., Marino, J., MartinezChantar, M., Nawroth, M.L., SanchezGarcia, R., Sharma, D., Saxena, N.K., Singh, N., Vlachostergios, P.J., Guo, S., Honoki, K., Fujii, H., Georgakilas, A.G., Amedei, A., Niccolai, E., Amin, A., Ashraf, S.S., Boosani, C.S., Guha, G., Ciriolo, M.R., Aquilano, K., Chen, S., Mohammed, S.I.,. Azmi, A.S., Bhakta, D., Halicka, D., and Nowsheen, S. (2015). Sustained proliferation in cancer: mechanisms and novel therapeutic targets. Semin Cancer Biol. 35:S25S54. doi: 10.1016/j.semcancer.2015.02.00 6.
Gadano, A., Gurni, López, A., Ferraro, P. and Carballo, M. (2002). In vitro genotoxic evaluation of the medicinal plant Chenopodium ambrosioides L. J. Ethonopharmacol. 81:11-16.

https://www.who.int/news-room/factsheets/detail/cancer. accessed 30/05/2019

Hur, Y.M., Kim, S.M., Choi, Y.W. and Park, K.Y. (2000). Inhibition of tumor formation and changes in hepatic enzyme activities by kimchi extracts in sarcoma 180 cell transplanted mice. J Food Sci Nutr. 5:4853.

James, G.C. and Natalie, S. (2001). Microbiology: a laboratory manual. 3rd ed. Redwood City: Benjamin/Cummings Publishing Company.

Khanna, N. and Sharma, S. (2013). Allium cepa root chromosomal aberration assay: a review. Indian J. Pharm. Biol. Res. 1(3):105-119.DOI: 10.30750/ijpbr.1.3.15.

Knoll, M.F., Silva, A.C.F., Tedesco S.B. and Canto-Dorow, T.S. (2006). Effects of Pterocaulon polystachyum DC. (Asteraceae) on onion (Allium cepa) roottip cells. Genet. Mol. Biol. 29: 539-542.

Kris-Etherton, P.M., Hecker, K.D., Bonanome, A., Coval, S.M., Binkoski, A.E., Hilpert, K.F., Griel, A.E., Etherton, T.D. (2002). Bioactive compounds in foods: their role in the prevention of cardiovascular disease and cancer [Review]. Am J Med. 113: 71S-88S.

Kwak, C.K., Park, S.C., and Song, K.Y. (2012). Doenjang, a fermented soybean paste, decreased visceral fat accumulation and adipocyte size in rats fed with high fat diet more effectively than non fermented soybeans. J. Med Food. 15:1-9.

Lasebikan, A.B., and Olorode, O. (1972). Morphological variation and cytological aberrations in the natural population of Zonocerus variegatus L. (Orthoptera: Pyrgomorphidae). Bull Entomol Soc Nigeria. 3:127-133.

Marshall, E and Mejia, D. (2011). Traditional fermented food and beverages for improved livelihoods. Rural 
Infrastructure and Agro-Industries Division Food and Agriculture Organization of the United Nations Rome.FAO diversification booklet 21. ISBN 978-92-5-107074-1.

Motarjemi, Y. (2002). Impact of small scale fermentation technology on food safety in developing countries. Int J Food Microbiol. 75:213- 229.

Mueller, T, and Voigt, W. (2011). Fermented wheat germ extract - nutritional supplement or anticancer drug? Nutr. J..1089.1186/1475-2891-10-89.

Obe, G, Pfeiffer, P., Savage, J.R.K., Johannes, C., Goedecke, W., Jeppesen, P., Natarajan, A.T., Mart' ınez-López W., Folle, G.A., Drets, M.E. (2002). Chromosomal aberrations: formation, identification and distribution. Mutat. Res. 504:17-36.

Odunfa, S.A. (1981). Microbiology and amino acid composition of ogiri - a food condiment from fermented melon seeds. Die Nahrung. 25: 811-816.

Park, K.Y. (1995). The nutritional evaluation and antimutagenic and anticancer effects of kimchi. J Korean Soc Food Sci Nutr. 24:169-182.

Park, K., Jeong, J., Lee, Y. and Daily III, J. (2014). Health Benefits of Kimchi (Korean Fermented Vegetables) as a Probiotic Food. J Med Food. 17 (1): 6-20

Periyanayagam, K., Kasirajan, B., Karthikeyan, V., Indumathi, R. and Kumuda, T. (2013). Vitis Vinifera.L (Vitaceae) leaves towards antimitotic and antiproliferative activity in anticancer drug discovery. Innovare Jo of Health Sci $1(3): 32-3$

Qaddouri, B., Guaadaoui, A., Bellirou, A., Hamal, A., Melhaoui, A., Brown, G.W., Bellaoui, M. (2009). The budding yeast 'Saccharomyces cerevisiae' as a drug discovery tool to identify plant-derived natural products with anti-proliferative properties. eCAM. 1-5 doi:10.1093/ecam/nep069.

Selhub, E.M., Alan, C., Logan, A.C., and Bested, A.C. (2014). Fermented foods, microbiota, and mental health: ancient practice meets nutritional psychiatry. JPHA. 33(2): 1-12.

Solange, B. T. and Haywood (IV), D. L. (2012). Bioindicator of Genotoxicity: The Allium cepa test, environmental contamination, Dr. Jatin Srivastava (Ed.). ISBN: 978-953-51-0120-8, InTech. Available online:http://cdn.intechopen.com/pdfswm/45127.pdf. Accessed 06/07/2017

Walker, P.M.B. (1954). The mitotic index and interphase processes. J.Exp.Biol.31: 814.

World Health Organisation. (2018). Available online: https://www.who.int/news-room/factsheets/detail/cancer. Accessed 19/03/2020. 